\title{
Foundation of Lease Finance: The Case of Nepal
}

\section{Suman Acharya, PhD}

\section{Email: sumanacharaya@gmail.com}

\begin{abstract}
As the concept of lease finance has been emerged only after World War II in the community of bankers, it has proved itself as one of the inadvertent source of corporate finance in contemporary time. Moreover, under the two fork of the lease procedure, operating lease is practiced by the economic community as complementary source of their living standard for short period of time in day to day life whereas many leasing company are to a leg up providing financial lease at a dead heat market from where many business community revive their economic condition professionally quick as a flash. As the bank loan becomes a tall order for the person or the organization as it is rigid in procedure and repayment, they prefer to use lease finance to operate their organization in stable condition. Lease finance is supportive to infrastructure development and economic growth of the country with the availability of capital resources as flexible source of financing.
\end{abstract}

\section{Introduction}

Unlimited wants of humans have called for contractual relations to address the scarcity of the resources. It necessitates full or partial support from the person in abundance. Now that lease finance is a method of long term and medium term financing with the relationship subsisting between lessor and lessee with contractual agreement. In lease finance, owner becomes lessor and user becomes lessee. Consequently, owner handovers possessory rights of asset to lessee for certain period of time as agreed. There can be separate agreement between lessor and suppliers. Lease finance may be both in asset and capital. Here, leasing company may emanate both bank and nonbank company under the licensing policy of the central bank under prevailing jurisdiction and laws. 


\section{Types of Lease}

- Financial Lease: As asset has been handed over for certain period of time, owner imparts all risk and return of the asset to the lessee under agreed rental return till the expiry of lease period. It has primary and secondary period of financial lease in which primary period in non-cancelable and secondary period is expansionary to particular point of time. It is like a sale for tax purpose because it will be there in sale category in balance sheet of the owners. It is also called capital lease.

- Operating Lease: It covers small span of economic life in which risk and rewards are not fully transferable to the lessee. Owner puts most of the rights self and grants only certain possessory user rights to lessor. Rental return from asset is far less than actual value of owner's investment in operating lease. It makes no difference in ownership status. It grants opportunity to cancel lease with prior notice to both parties each other.

\section{- Others ${ }^{1}$}

- Leverage Lease: There is the arrangement of agreement between and among lessor, lessee and lender. Owner of the assets makes opportunity to get benefit from depreciation of the asset. In fact, lender lends on behalf of the owner of the asset to make lease possible to lessee. It is more likely suitable for immoveable and expensive assets i.e. real estate, aircraft etc. Owner or lessor may have equity participation in leverage lease.

○ Sale and Leaseback Arrangement: It is like sale and leaseback arrangement of contract. Owner handovers the asset or capital for certain period of time to lessor with full rights. Even there is no ownership of lessor until the expiry of the lease agreement. If there is the ownership transfer provision, it is allowed after the expiry of lease contract. It resembles with installment arrangement. Many often it occurs less likely.

- Percentage Lease: Lessee pays base amount of rent and certain percentage of their level of revenue if so has been increased as their earning. It is most flexible method of repayment for the lessee. 
- Cross Border Lease: A lessor and lessee can be from two or more nations. They can get entry in lease for the purpose of tax management and settlement. Most of the European Countries have been practicing these sorts of lease. It has been widely used in financing infrastructure development in emerging nations.

○ Wet and Dry Lease: It has especially been used in aircraft leasing. Under wet leasing, lessor provides aircraft along with crew member. Sometimes, it may include maintenance service as well. However, dry lease is reverse to wet lease which has no crew member and maintenance facilities.

- Swap Lease: It is the transfer of lease from one person to another with same terms and conditions of lease. It is especially suitable in vehicle lease because a lease can be transferred to other person from one person in a running cost with same lease terms and conditions.

\section{Features of Lease Financing}

In lease finance, lessor is generally the owner and lessee is the holder. Sometimes lessor acquires the assets from dealer or manufacturer by concluding agreement and delivers it to the lessee. Lessee gets possessory rights of economic use with rental payment in regular interval of time. They may or may not conclude sublease agreement, which depends on the provision of lease agreement. The features and process of lease financing can be depicted as under as prescribed by Chandraiah (2004). ${ }^{2}$

\section{Lease Arrangement}

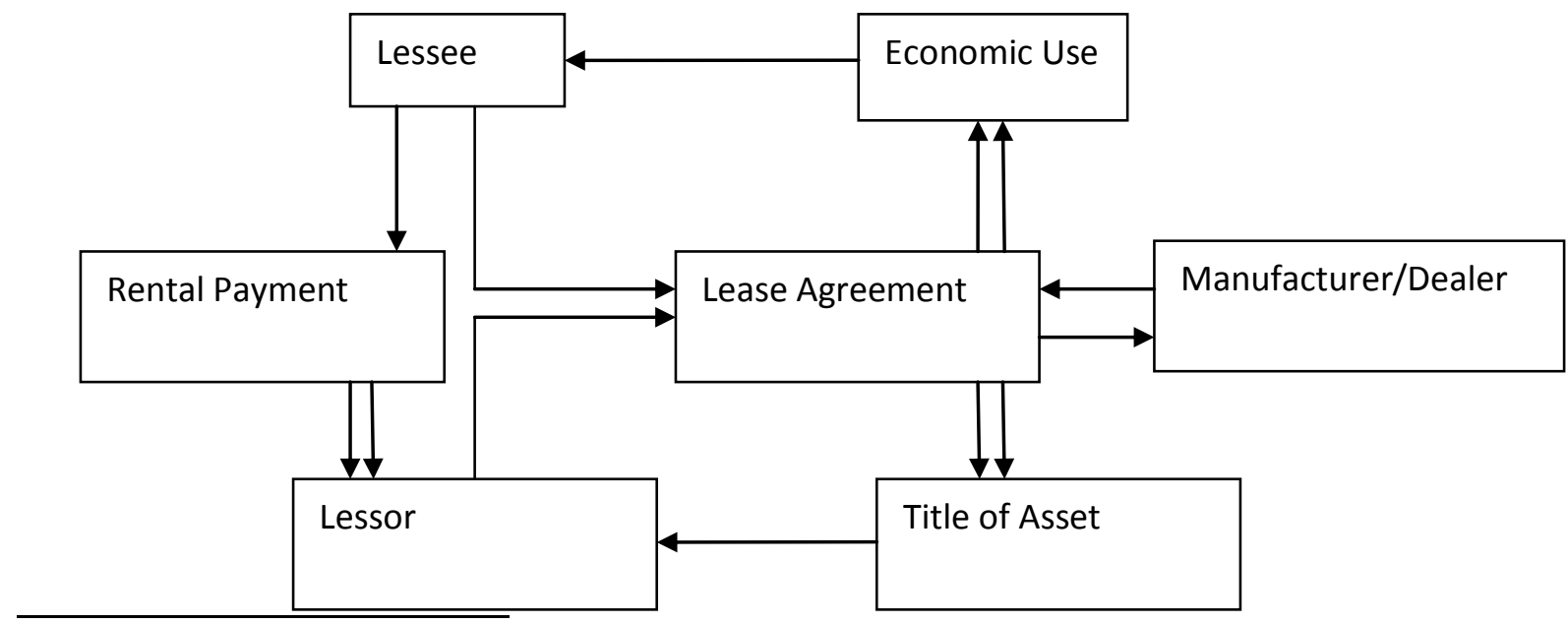

2 E. Chandraiah. Evaluation of Lease Financing. 35 (2004). Concept Publishing Company: New Delhi. 
Lease finance, as a modern from of corporate financing, is an alternative form of loan financing of the banks. It is also alternative to corporate financing method, which has been introduced by bankers only after World War II. However, the concept of lease occurred in medieval era. Base on the country specific law, there can be special purpose vehicle for lease financing which can be established by banks and non-banks companies as well. It has separate procedure of financing and operation method. It is alternative to installment financing as well because there will be loan in installment financing to the buyer instead of owner but in lease financing there will be no difference in ownership position. If there is the provision of ownership transfer, it may come finally. Lease system can be used for short-term, medium-term and long-term agreement. However, financial lease is above than one year generally. It is applicable for both moveable and immoveable property as per the policy and law of the country. There can be the issue of insurance which is generally done by ultimate owner or the lessor, which transfers risk to insurance system under prevailing laws of the country. Under the lease finance, lessor may get tax advantage for the time being on assets. They used to make lease finance with the consideration of depreciation of the assets if so is applicable.

\section{Sublease}

Sublease is important part of lease finance which has two pronged process; first, a lessor leases an assets to lessee and next, even lessee can lease an asset of lessor to third party with their separate agreement. Yet, the responsibility of primary lessee cannot be ended and condition of lease agreement made with lessor by primary lessee cannot be overlooked. ${ }^{3}$ There must be consent of principal lessor about sublease in agreement. In case of swap provision, new lessee will have full responsibility to primary lessor.

3 IFRS 16 mentions that 'A sublease is a transaction whereby a lessee leases an asset from a lessor (head lease) and the lessee then releases the same asset (as intermediate lessor) to another third party lessee (sublease)'. IFRS 16 requires an intermediate lessor to classify the sublease as a finance lease or an operating lease as follows: If the head lease is a short-term lease that the entity, as a lessee, has accounted for by recognising the lease payments as an expense on a straight-line basis over the term of the lease, the sublease must be classified as an operating lease. Otherwise, the sublease must be classified by reference to the right-of-use asset arising from the head lease, rather than by reference to the economic useful life of the underlying asset (such as the item of property, plant or equipment that is the subject of the lease). https://www.ifrs.org/issued-standards/list-of-standards/ifrs-16-leases/. (Last Visited on 8/23/2020). 


\section{Sublease Process}

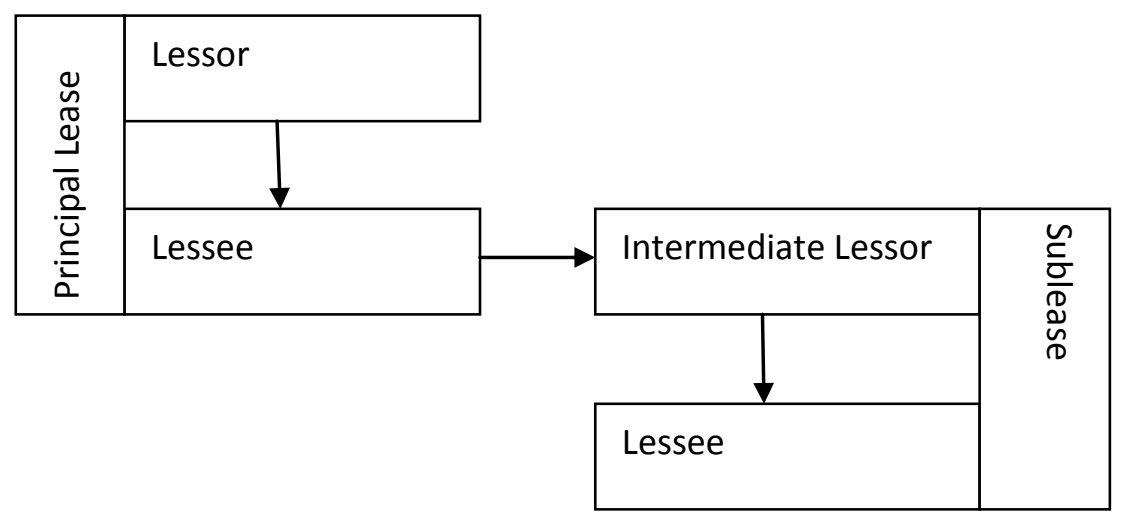

\section{Role of Banks in Lease Financing}

In many countries, banks work as lessor and lender. As a lessor, it grants certain entitlement to lessee for use and as a lender it grants loan to lessor with the guarantee of the leased assets. As a lender, banks finances owner with the guarantee of the asset as collateral and lessor himself finances the lessee with his own terms and conditions. Bank can make loan finance to lessee in case they have the production capacity and collateral capacity with long-term contract of real estate and other project financing system. It has been guided by contract and other specialized legislation and practices of the country. Lease finance is different than installment financing because a kind of loan goes to buyer in installment which is reverse to lease financing. Owner gets lending from banks with due collateral guarantee. In fact leased assets are hypothecated in the banks by the lessor. ${ }^{4}$

\section{Component of Lease Financing}

\begin{tabular}{|l|l|l|}
\hline S.No. & Issues & Explanation \\
\hline 1. & Role of Central Bank & $\begin{array}{l}\text { As there are the involvement of banks and financial institutions, } \\
\text { the company providing lease finance are registered and regulated } \\
\text { by the central bank. As a lease finance needs the involvement of } \\
\text { banks and financial institution including public limited company } \\
\text { having certain amount of capital, the central bank makes } \\
\text { regulation as a monetary authority. As a procedural matter, there }\end{array}$ \\
\hline
\end{tabular}

$4 \quad$ Vide Vinod Kothari. Lease Finance and Hire-Purchase. 26 (1986). Wadhwa and Company. 


\begin{tabular}{|c|c|c|}
\hline & & $\begin{array}{l}\text { can be the role of other regulators as well for the purpose of } \\
\text { permission. }\end{array}$ \\
\hline 2. & $\begin{array}{l}\text { Leasing } \\
\text { Company/Special } \\
\text { Purpose Vehicle }\end{array}$ & $\begin{array}{l}\text { Even bank and non-bank company having minimum standard of } \\
\text { the capital receive licenses for lease finance from central bank. } \\
\text { Leasing company may burrow loan from Bank as a source of } \\
\text { corporate finances. Lessor here refers to financial leasing } \\
\text { company. It can be banks and financial institutions including } \\
\text { public limited company having license from the central bank to } \\
\text { operate financial leasing. The financiers of non-bank leasing } \\
\text { company as a loan will be banks and financial institutions based } \\
\text { on collateral. }\end{array}$ \\
\hline 3. & Lease Securitization & $\begin{array}{l}\text { For the lease financing, the originator may establish special } \\
\text { purpose vehicle which can issue securities in the backing of the } \\
\text { lease and the payment made by the lessee. In case of the } \\
\text { liquidation occurred, holder of the lease backed securities get } \\
\text { first priority. Sometimes, there may occur the situation of } \\
\text { liquidation of originator. In such case, it would be better to } \\
\text { construe Special purpose vehicle and originator as separate entity } \\
\text { although it is formed for special purpose or short term purpose } \\
\text { both. }\end{array}$ \\
\hline 4. & Suppliers & $\begin{array}{l}\text { It refers to the producer or dealer of moveable property and the } \\
\text { owner for immoveable property. They are ready to provide assets } \\
\text { to the leasing company as agreed between them. }\end{array}$ \\
\hline 5. & $\begin{array}{l}\text { Bank Loan vs. Lease } \\
\text { Finance }\end{array}$ & $\begin{array}{l}\text { Lease finance is not construed similar with bank loan. The lease } \\
\text { finance is softer in nature than Bank loan as because there is } \\
\text { fixed repayment under lease financing and is not fluctuated as } \\
\text { per the vacillation in the market. It is durable and efficient source } \\
\text { of corporate financing. Under the bank loan, it may be changed } \\
\text { as per market scenario of money flow. }\end{array}$ \\
\hline 6. & $\begin{array}{l}\text { Lease Finance vs. } \\
\text { Hire Purchase }\end{array}$ & $\begin{array}{l}\text { Lease finance and hire purchase are significantly different. The } \\
\text { owner of the asset ultimately relies on lessor in lease financing }\end{array}$ \\
\hline
\end{tabular}




\begin{tabular}{|c|c|c|}
\hline & & $\begin{array}{l}\text { and lessee is only the possession holder. Under the lease } \\
\text { contract, lessee uses the asset including equipments. Under the } \\
\text { hire purchase, hirer psychologically gets ownership from the } \\
\text { very down payment although a full right of ownership is } \\
\text { acquired only after the final installment payment. There may or } \\
\text { may not be ownership transfer clause in lease contract. }\end{array}$ \\
\hline 7. & Status of Lessee & $\begin{array}{l}\text { Lessee utilizes the capital under lease finance for the fixed } \\
\text { period of time. There is the primary and secondary period for } \\
\text { lease financing. Primary period in non-cancelable whereas } \\
\text { secondary period is prolonged period. It can be the customer of } \\
\text { burrower of the capital from leasing company. They want to } \\
\text { reduce their expenditure by accepting leasing capital. As loan } \\
\text { financing is expensive, they prefer to get capital from lease } \\
\text { financing having regular fixed payment during their leasing } \\
\text { period. }\end{array}$ \\
\hline 8. & $\begin{array}{l}\text { Lessee and Bank } \\
\text { Loan }\end{array}$ & $\begin{array}{l}\text { Based on the available productivity of the capital and other } \\
\text { resources subject to collateral, lessee can get bank loan. In fact, } \\
\text { getting bank loan is separate procedures than lease financing. }\end{array}$ \\
\hline 9. & $\begin{array}{l}\text { Involvement of the } \\
\text { Insurance }\end{array}$ & $\begin{array}{l}\text { There can be two-pronged aspect of the insurance in lease } \\
\text { financing; one is insurance made by lessor to protect their assets } \\
\text { and next is insurance made by lessee in their operating procedure } \\
\text { and their outcome to protect their available assets. Even based on } \\
\text { the insurance scenario, bank can make project loan financing to } \\
\text { the lessee. }\end{array}$ \\
\hline 10. & $\begin{array}{l}\text { Use of Financial } \\
\text { Lease }\end{array}$ & $\begin{array}{l}\text { The presence of financial lease shows the development level of } \\
\text { the economy. It is one of the architects to run national economy. } \\
\text { The resources from financial lease can be utilized by government } \\
\text { sector, public sector and private sectors. Lessor can make } \\
\text { financing in aircraft, vehicles, real estate and many more. It can } \\
\text { be source for long term and medium term financing. }\end{array}$ \\
\hline
\end{tabular}




\section{Provision on Lease Contract}

Lease contract is the consumption, possession and the use of goods having entitlement of somebody else without diminishing its values with the payment of interests or installment. The goods which are destroyable in consumption cannot be leased. ${ }^{5}$ Although lessee cannot change the status of goods, it can do repair, maintain, improve, and renovate it as contracted. ${ }^{6}$ Leased goods require to be used in good faith and prudently. ${ }^{7}$ If lessor has the duty to repair, maintenance or renovation, it can be done of lessee with rent adjustment. ${ }^{8}$ If the goods are damaged, destroyed or unusable, it has to be immediately informed to lessor. ${ }^{9}$ Yet, if it is destroyed without the proper care of lessee or their member, lessee will be liable to restore the goods in previous conditions except force majeure. ${ }^{10}$ Lessee has the duty to pay lease rent timely as contracted. ${ }^{11}$ There are specific time period of contract of lease. ${ }^{12}$ Leased goods can be subleased if so is allowed by the owner in writing. ${ }^{13}$ Leased goods should be returned once it has been terminated or matured. ${ }^{14}$ If the lease of immoveable property more than 10 years to be concluded, it has to be registered in concerned government body. It cannot be leased to foreign person who cannot acquire by law in the absence the decision of the government of Nepal. There

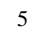

Civil Code § Sec. 610 (2074). http://www.moljpa.gov.np/en/wp-content/uploads/2018/12/Civil-code.pdf. (Last Visited on 6/4/2020).

Id. § Sec. 611.

Id. § Sec. 612.

Id. § Sec. 613.

Id. § Sec. 614.

Id. § Sec. 615.

Id. § Sec. 616 .

Id. § Sec. 617. (617. Validity period of contract of lease: (1) No contract of lease concluded in relation to the following goods shall remain valid for more than the following period: (a) Thirty-five years in the case of housing land leased for the construction of a building or housing land in use after construction of a building therein, (b) Thirty-five years in the case of the land leased for the purpose of servitude, (c) Forty years in the case of the land leased for the purpose of construction, development and 349 operation of the infrastructures such as industrial structure, roads, canals, electricity generation, (d) Twenty years in the case of land for farming; (e) Nineteen years in the case of house and land leased for the purposes other than that referred to in clause (a), (b), (c) or (d), (f) Fifteen years in the case of a motor vehicle, (g) Fifteen years in the case of machinery equipment other than a motor vehicle, (h) Fifteen years in the case of machinery equipment other than that referred to in clause (f) or (g), (i) Ten years in the case of a domestic animal, (j) Ten years in the case of goods other than that set forth in this Section having regard to their life and nature. (2) Notwithstanding anything contained in sub-section (1), the parties may extend the validity period of the contract of lease, subject to the validity period of the contract, before expiry of the period referred to in such a sub-section. (3) Notwithstanding anything contained in sub-section (2), the parties to a contract of lease may decide whether to extend the period of the contract of lease having regard to the place where the leased house and land are situated and the nature of the goods.)

Id. § Sec. 618.

Id. § Sec. 619. 
will be the right of lessee to structure if so is not contracted otherwise. ${ }^{15}$ If the contractual provisions are not realized, the lease contract will be terminated. ${ }^{16}$

\section{Conclusion}

Lease finance is the long term and medium term sources of corporate financing, which consists of operating and capital lease. So, operating lease is short term source whereas financial lease is long term source in nature. As an important architect of the national economy, financial lease may provide capital for all the economic pillars of the country as life of its own, which accelerates the national economy. Leasing company may utilize the resources of private sector thorough the means of corporate financing to a great deal. Leasing company may finance lessee with moveable, immoveable and cash form. Sometimes, the lessor and suppliers can be different entity which may enter into contractual relations to be the party in financial lease procedures. As the lease contract provisions are found in Civil Code, 2017 AD (2074 BS) in Nepal, there is no specialized separate law in the field of lease finance related issues till this date. It would be more systematic procedure of lease finance if specialized law has been enacted and harmonized.

\section{'The End...'}

$\begin{array}{ll}15 & \text { Id. } \S \text { Sec. } 620 . \\ 16 & \text { Id. } \$ \text { Sec. } 621 .\end{array}$

